Jurnal Indonesia Sosial Teknologi: p-ISSN: 2723 - 6609

e-ISSN : 2745-5254

Vol. 2, No. 11 November 2021

\title{
ANALISIS PENGARUH BERITA BOHONG DI SOSIAL MEDIA TERHADAP KEPUTUSAN MASYARAKAT INDONESIA MELAKUKAN VAKSINASI COVID-19
}

\author{
Hendry Naufal Marbella ${ }^{1}$, Nadira Hanifah Nur'aini ${ }^{2}$, Shafwan Agung ${ }^{3}$, Nur Aini \\ Rakhmawati ${ }^{4}$. \\ Institut Teknologi Sepuluh Nopember Surabaya, Jawa Timur, Indonesia \\ Email: hendry.19052@mhs.its.ac.id ${ }^{1}$,nadiranuraini.19052@mhs.its.ac.id ${ }^{2}$, \\ shafwan.19052@mhs.its.ac.id ${ }^{3}$, nur.aini@is.its.ac.id ${ }^{4}$
}

\begin{abstract}
Abstrak
Wabah COVID-19 menyebabkan kepanikan, ketakutan, bahkan kematian di seluruh dunia. Program vaksinasi menjadi alternatif solusi untuk segera mengakhiri wabah ini. Penelitian ini mengungkap keputusan vaksinasi COVID-19 oleh masyarakat Indonesia berdasarkan pemberitaan bohong yang ada pada media sosial. Opini yang berkembang membuat masyarakat memiliki pandangan yang berbeda-beda untuk melakukan vaksinasi COVID-19. Penelitian ini bertujuan untuk menentukan opini dan pertimbangan masyarakat dalam melakukan vaksinasi COVID-19. Penelitian ini dilakukan menggunakan metode kuantitatif dengan pendekatan deskriptif. Selain itu, alat yang digunakan untuk meneliti adalah survei daring. Hasil respons yang didapatkan melalui metode survei membuktikan bahwa lebih dari $84 \%$ responden mengaku pemberitaan tentang COVID-19 lebih sering dibagikan kepada keluarga daripada pihak lain. Berita bohong setidaknya diterima oleh lebih dari $40 \%$ responden melalui media sosial. Hampir setengah dari jumlah responden menyatakan bahwa mereka akan berpikir dua kali untuk menerima vaksinasi COVID-19 setelah melihat simulasi pemberian berita bohong yang ada di media sosial. Hal ini juga didukung oleh penurunan jumlah responden yang bersedia menerima vaksin baru COVID-19 dibandingkan dengan jumlah responden yang belum menerima berita bohong mengenai vaksinasi COVID-19. Pada akhirnya, responden ternyata masih mempercayai lembaga resmi pemerintah sebagai salah satu sumber informasi mengenai vaksinasi COVID-19.
\end{abstract}

Kata kunci: berita bohong; COVID-19; media sosial; opini; pertimbangan; vaksinasi

\section{Abstract}

The COVID-19 outbreak is causing panic, fear and even death worldwide. The vaccination program is an alternative solution to immediately end this outbreak. This study reveals the decision to vaccinate against COVID-19 by the Indonesian people based on fake news on social media. The growing opinion makes people have different views on vaccinating COVID-19. This study aims to determine public opinion and considerations in carrying out COVID-19 vaccination. This research was conducted using quantitative methods with a descriptive approach. In addition, the tool used for research is an online survey. The results of the responses obtained through the survey method proved that more than $84 \%$ of respondents admitted that 
Hendry Naufal Marbella, Nadira Hanifah Nur'aini, Shafwan Agung, Nur Aini Rakhmawati

news about COVID-19 was more often shared with their families than other parties. Fake news is at least accepted by more than $40 \%$ of respondents through social media. Nearly half of the respondents stated that they would think twice about receiving a COVID-19 vaccination after seeing fake news simulations on social media. This is also supported by a decrease in the number of respondents who are willing to receive the new COVID-19 vaccine compared to the number of respondents who have not received fake news about COVID-19 vaccination. In the end, respondents turned out to still trust official government institutions as a source of information regarding COVID-19 vaccination.

Keywords: hoax; COVID-19; social media; opinion; consideration; vaccination

\section{Pendahuluan}

Dunia dikejutkan dengan adanya wabah virus Corona (COVID-19) yang menginfeksi hampir seluruh negara di dunia pada awal tahun 2020. Tidak peduli negara maju, berkembang, maupun miskin semua mengalaminya. Pada awalnya, ada negara yang percaya dan berusaha untuk segera mengantisipasinya, namun, ada pula negara yang tidak percaya, bahkan cenderung 'menyepelekan' wabah ini. Virus Corona ini juga menginfeksi negara Indonesia, mulai terdeteksi masuk di Indonesia sejak awal Maret 2020 (Damaledo, 2021). Mengetahui hal tersebut, pemerintah Indonesia segera bertindak untuk bisa segera menyelesaikan kasus ini. Tindakan yang telah dilakukan pemerintah Indonesia, di antaranya adalah menyiapkan 100 rumah sakit dengan ruangan standar isolasi dan menginstruksikan gerakan social distancing (Ihsanuddin, 2020). Selama proses mengatasi virus ini, terjadi banyak kepanikan dan ketakutan yang melanda warga Indonesia, sampai muncul sebuah fenomena panic buying (Pranita, 2020). Karena hal ini banyak masyarakat dan bahkan pengamat pemerintah mengatakan bahwa pemerintah Indonesia gagap dalam mengatasi dan menjelaskan kebijakan serta kondisi terkait virus Corona (Tim COVID-19 Filantropi, 2020).

Didasari rasa tidak percaya terhadap pemerintah, mendadak banyak orang tibatiba menjadi ahli COVID-19. Semua hal dikomentari dan informasi yang belum jelas validasinya, disebarluaskan begitu saja melalui media sosial. Selama pandemi COVID19, media sosial memang menjadi sumber informasi penting bagi masyarakat dalam memantau perkembangan kasus COVID-19 serta mengetahui tata cara pencegahan dan penanganan COVID-19 (Kalia, 2021). Beragam jenis informasi dapat diakses oleh masyarakat baik informasi yang diperoleh dari akun resmi maupun yang belum jelas sumbernya. Pertukaran informasi ini menjadi sangat cepat, terlihat dari peningkatan pengiriman pesan pada media sosial Facebook, Instagram, WhatsApp sebesar 50\% dari bulan-bulan sebelumnya pada daerah yang paling terdampak COVID-19 (Schultz, A., \& Parikh, 2020). Tentunya, dari sekian banyak penggunaan media sosial tidak dapat dipastikan secara pasti bahwa semua informasi adalah benar dan dapat dipercaya. Di satu sisi terdapat informasi dan berita faktual dan terpercaya, namun berita-berita tersebut juga tidak jarang tertutupi dengan berita bohong atau hoaks yang bertebaran. 
Hoaks atau berita bohong sendiri merupakan informasi palsu yang dibuat-buat hingga serupa dengan konten pada layaknya berita, namun tanpa adanya proses yang memastikan akurasi dan kredibilitas dari informasi tersebut (Lazer et al., 2018). Terdapat tujuh tipe klasifikasi berita bohong menurut (Wardle, 2020), diurutkan berdasarkan tingkat intensi merugikan dari rendah ke tinggi, antara lain

1. satire atau parodi-tidak bermaksud merugikan namun memiliki kemungkinan menipu;

2. false connection (koneksi palsu) - judul berita, visual atau takarir tidak mendukung isi konten;

3. misleading content (konten menyesatkan) - informasi disesatkan untuk menjatuhkan suatu

4. false context (konteks palsu) - konten aktual dibagikan dengan konteks yang palsu;

5. imposter content (konten tiruan)-konten yang palsu namun berkedok sumber terpercaya;

6. manipulated content (konten manipulasi) — informasi atau gambar yang aktual namun dimanipulasi untuk menipu; dan

7. fabricated content (konten buatan) - konten yang $100 \%$ palsu, dibuat untuk menipu dan merugikan.

Menurut sebuah penelitian oleh (Zhu et al., 2012) apabila seseorang sudah terpapar informasi yang salah meskipun hanya sebentar saja, informasi yang salah ini bisa tersimpan di memori manusia sebaik informasi yang benar. Tentu hal ini akan mengkhawatirkan apabila seseorang dengan tidak sengaja menyebarkan informasi yang salah ini hanya karena paparan berita bohong sekilas saja. Memang tidak semua orang langsung percaya dengan informasi-informasi yang tersebar di dunia maya, masih ada orang yang mengecek kebenarannya. Namun, dari penelitian lain, rupanya orang-orang yang sudah melakukan pengecekan fakta ini masih saja bisa terpapar dengan berita-berita bohong, yang berarti tidak ada orang di dunia ini yang bisa terlepas dari penyimpangan informasi karena berita-berita bohong ini (Saling, Mallal, Scholer, Skelton, \& Spina, 2021).

Di Indonesia, salah satu lembaga yang memerangi hoaks adalah MAFINDO (Masyarakat Anti Fitnah Indonesia), sebuah komunitas anti-hoaks, tersertifikasi secara internasional oleh Internasional Fact Checking Network (IFCN), dengan tujuan sebagai pelindung masyarakat Indonesia dari berita hoaks (Mafindo, 2021). Dari pengamatan peneliti dengan melakukan pengindeksan melalui mesin telusur Google, ditemukan lebih dari 3.300 hasil pencarian dengan kata kunci "vaksin covid" per tanggal 9 November 2021 yang merupakan berita-berita bohong yang telah disanggah dengan berbagai sumber yang lebih kredibel oleh MAFINDO melalui situs webnya, turnbackhoax.id.

Kini pemerintah mulai mengadakan program vaksinasi COVID-19 sebagai satusatunya cara yang paling efektif dalam menghentikan pandemi ini dengan mengurangi risiko kematian yang disebabkan virus COVID-19 (Kemenkes, 2021) (Dhewantara, 2021). Sayangnya, tak ada yang dapat menghentikan berita bohong mengenai vaksin 
Hendry Naufal Marbella, Nadira Hanifah Nur'aini, Shafwan Agung, Nur Aini Rakhmawati

COVID-19 tersebar, sekalipun adanya MAFINDO atau situs pengecekan fakta lainnya, tidak semua orang melakukan pengecekan fakta informasi yang mereka dapat dengan informasi yang kredibel dan jelas sumbernya ( Zignal Labs, 2017). Dengan maraknya berita bohong yang beredar ini dikhawatirkan dapat memengaruhi keinginan masyarakat dalam melakukan vaksin COVID-19. Didukung oleh penelitian sebelumnya dengan responden dari Amerika Serikat dan Britania Raya, hasilnya ditemukan bahwa berita yang berisi hal-hal saintifik yang tidak benar rupanya menurunkan kemauan untuk vaksin orang-orang di Amerika Serikat dan Britania Raya (Loomba, de Figueiredo, Piatek, de Graaf, \& Larson, 2021).

Diperparah dengan masih banyaknya masyarakat Indonesia sekitar 23\% yang menyebarkan cuitan bersentimen negatif di media sosial Twitter menurut penelitian (Rakhmawati, Aditama, Pratama, \& Wiwaha, 2020) Hal ini tidak akan mencerahkan suasana media sosial yang sudah dipenuhi dengan berita bohong. Dengan timbulnya berbagai macam opini di masyarakat Indonesia terkait vaksin COVID-19, pada penelitian ini penulis akan menganalisis respons-respons masyarakat terhadap berita bohong terkait vaksin COVID-19 sehingga kita dapat mengetahui bagaimana keputusan yang diambil oleh masyarakat Indonesia secara umum. Dengan penelitian ini, pembaca maupun peneliti akan mendapatkan informasi terkait sentimen masyarakat Indonesia terhadap program vaksinasi COVID-19 yang ada saat ini. Melalui penelitian ini pula, kita sebagai warga negara yang baik dapat memperhatikan dan menyikapi dengan bijak terhadap semua informasi yang kita diterima.

Penelitian serupa sudah pernah dilakukan oleh peneliti di negara-negara lain seperti Amerika Serikat dan Britania Raya. Hasil penelitian tersebut dirasa tidak relevan dengan kondisi yang ada di Indonesia dikarenakan beberapa faktor seperti perbedaan gaya hidup dan cara masyarakat Indonesia menyikapi sesuatu yang ada di media sosial. Hal ini menjadi salah satu keunggulan penelitian ini dalam meneliti sentimen masyarakat terhadap program vaksinasi COVID-19 di Indonesia. Dengan adanya penelitian ini, diharapkan dapat menjadi landasan atau sumber referensi untuk penelitian selanjutnya di masa yang akan datang.

\section{Metode Penelitian}

Dalam penelitian ini metode yang digunakan adalah metode penelitian kuantitatif dengan pendekatan deskriptif. Metode penelitian kuantitatif menurut (Sugiyono, 2016) merupakan metode penelitian yang berlandaskan pada filsafat positivisme, digunakan untuk meneliti pada populasi atau sampel tertentu, teknik pengambilan data menggunakan instrumen penelitian, analisis bersifat kuantitatif/statistik dengan tujuan untuk menguji hipotesis yang telah ditetapkan. Sedangkan pendekatan deskriptif adalah pendekatan berdasarkan data-data yang perlu dianalisis dan diinterpretasi sehingga dapat ditemukan solusi atas masalah yang ada sekarang.

Data-data yang digunakan dalam penelitian ini diambil menggunakan metode survei berupa pembagian kuesioner melalui Google Form. Menurut (Effendi, 2012), metode survei adalah mengambil sampel dari satu populasi dan menggunakan kuesioner 
sebagai alat pengumpulan data yang pokok. Metode survei ini dilakukan kepada masyarakat Indonesia yang telah diklasifikasikan. Pengklasifikasian yang dimaksud, seperti berdasarkan usia, jenis kelamin, tingkat pendidikan tertinggi, jenis pekerjaan, agama, dan waktu yang dihabiskan di platform media sosial.

Pada penelitian ini penulis melakukan beberapa langkah penelitian untuk mendapatkan dan menganalisis data. Langkah-langkah penelitian yang dilakukan oleh penulis meliputi

1. pengumpulan berita bohong terkait vaksin COVID-19; dan

2. pengumpulan data eksperimen dengan kuesioner.

Berita bohong yang kami dapatkan ini akan digunakan sebagai pertanyaan dalam kuesioner kami. Responden akan diminta untuk memberi tanggapannya terhadap beritaberita tersebut untuk mengetahui seberapa setuju responden dengan berita yang tidak benar itu. Kami juga akan menanyakan mengenai penggunaan sosial media responden serta bagaimana kepercayaan mereka terhadap sumber berita yang mereka baca di sosial media. Media sosial dipilih karena dari sinilah kebanyakan orang mendapatkan beritaberita baik bohong maupun faktual mengenai COVID-19 paling banyak (Dang, 2021).

Agar responden merasa lebih nyaman dalam mengisi kuesioner, kami membagi pertanyaan-pertanyaan kami menjadi enam bagian. Bagian pertama, kami meminta data demografi singkat berupa usia, jenis kelamin, dan pekerjaan. Pertanyaan-pertanyaan ini kami adopsi dari laporan Survei Penerimaan Vaksin oleh (Kementerian Kesehatan, ITAGI, UNICEF, dan WHO, 2020). Bagian kedua merupakan pertanyaan garis dasar pemahaman vaksin COVID-19, yang berisi pertanyaan mengenai sudah tidaknya responden menerima vaksinasi COVID-19. Apabila responden menjawab belum, kami juga meminta alasan mereka. Pilihan jawaban merupakan hasil adopsi dari kuesioner yang dilakukan oleh (Loomba et al., 2021).

Pada bagian ketiga, kami ingin mengetahui sumber informasi vaksinasi COVID19 dan penggunaan media sosial responden. Pada bagian keempat kami memaparkan kepada responden berupa lima gambar informasi bohong, beserta pertanyaan mengenai pendapat responden setelah melihat gambar-gambar tersebut dan pendapatnya akan gambar tersebut. Bagian kelima, kami ingin mengetahui apakah responden pernah melihat konten-konten serupa seperti gambar yang kami berikan di media sosial. Ketiga bagian terakhir ini kami adopsi dari kuesioner pada penelitian oleh (Loomba et al., 2021).

Adapun gambar-gambar yang dipaparkan pada bagian keempat di kuesioner kami, merupakan tangkapan layar dari sebuah situs web dan empat konten media sosial yang merupakan sebuah hoaks dalam kategori misleading content. Kelima konten ini sudah dilakukan penelaahan dan pengecekan fakta dari berbagai sumber yang kredibel untuk memastikan bahwa konten-konten tersebut bukanlah hal yang benar. Pengecekan fakta ini dilakukan oleh MAFINDO (Masyarakat Anti Fitnah Indonesia), melalui situs webnya di turnbackhoax.id.

\section{Hasil dan Pembahasan}

\section{Karakteristik Responden}


Hendry Naufal Marbella, Nadira Hanifah Nur'aini, Shafwan Agung, Nur Aini Rakhmawati

Berikut merupakan karakteristik-karakteristik responden yang bersedia berpartisipasi dalam kuesioner yang telah diadakan penulis.

Tabel 1 Karakteristik Responden Berdasarkan Rentang Usia Rentang Usia Jumlah Responden Persentase

\begin{tabular}{cll}
\hline $17-30$ & 19 & $59,4 \%$ \\
\hline $31-40$ & 1 & $3,1 \%$ \\
\hline $41-50$ & 3 & $9,4 \%$ \\
\hline $51-60$ & 9 & $28,1 \%$ \\
\hline
\end{tabular}

Berdasarkan data tersebut dapat diketahui bahwa responden dengan rentang usia 17-30 berjumlah 19 (59,38\%), untuk rentang usia 31-40 berjumlah 1 (3,13\%), untuk rentang usia 41-50 berjumlah 3 (9,38\%), dan untuk rentang usia 51-60 berjumlah 9 $(28,13 \%)$. Sehingga dapat disimpulkan bahwa mayoritas responden yang tertarik akan kasus yang diangkat dalam kuesioner adalah masyarakat yang berada pada rentang usia 17-30, yaitu sebanyak 19 responden.

\begin{tabular}{|c|c|c|}
\hline Jenis Kelamin & Jumlah Responden & Persentase \\
\hline Laki-laki & 7 & $21,9 \%$ \\
\hline Perempuan & 19 & $59,4 \%$ \\
\hline Tidak ingin menjawab & 6 & $18,8 \%$ \\
\hline
\end{tabular}

Berdasarkan data tersebut dapat diketahui bahwa responden Laki-laki berjumlah 7 (21,9\%), responden Perempuan berjumlah 19 (59,4\%), dan yang tidak ingin menunjukkan jenis kelaminnya berjumlah $6(18,8 \%)$. Sehingga dapat disimpulkan bahwa mayoritas responden yang tertarik akan kasus yang diangkat dalam kuesioner adalah responden dengan jenis kelamin Perempuan, yaitu sebanyak 19 responden.

Tabel 3 Karakteristik Responden berdasarkan Pekerjaan

\begin{tabular}{lll} 
Pekerjaan & Jumlah Responden & Persentase \\
\hline Siswa/Mahasiswa & 19 & $59,4 \%$ \\
\hline PNS/Tentara/Polri/BUMN/BUMD & 1 & $3,1 \%$ \\
\hline Pegawai Swasta & 3 & $9,4 \%$ \\
\hline Wiraswasta/Pengusaha & 1 & $3,1 \%$ \\
\hline Lainnya & 8 & $25 \%$ \\
\hline
\end{tabular}

Berdasarkan data pada Tabel 3 tersebut dapat diketahui bahwa responden yang $\begin{array}{lllll}\text { bekerja sebagai Siswa/Mahasiswa berjumlah } 19 \quad(59,4 \%), & \text { sebagai }\end{array}$ PNS/Tentara/Polri/BUMN/BUMD berjumlah $1(3,1 \%)$, sebagai Pegawai Swasta berjumlah $3(9,4 \%)$, sebagai Wiraswasta/Pengusaha berjumlah $1(3,1 \%)$, dan sebagai 
pekerja serabutan berjumlah 8 (25\%). Sehingga dapat disimpulkan bahwa mayoritas responden yang tertarik akan kasus yang diangkat dalam survei adalah responden yang bekerja sebagai Siswa/Mahasiswa, yaitu sebanyak 19 responden.

\section{Variabel Terkait Dasar Pemahaman Vaksinasi COVID-19}

a. Apakah Anda atau salah satu anggota keluarga Anda atau teman, kolega, tetangga Anda pernah dinyatakan positif COVID-19?

\begin{tabular}{|c|c|c|}
\hline Jawaban & Jumlah Responden & Persentase \\
\hline $\mathrm{Ya}$ & 26 & $81,3 \%$ \\
\hline Tidak & 6 & $18,8 \%$ \\
\hline Mungkin & - & - \\
\hline
\end{tabular}

Berdasarkan data pada Tabel 4 dapat diketahui bahwa responden yang menjawab Ya berjumlah $26(81,3 \%)$, responden yang menjawab Tidak berjumlah $6(18,8 \%)$, dan tidak ada responden yang menjawab Mungkin. Sehingga dapat disimpulkan bahwa mayoritas responden menjawab Ya terkait pertanyaan 1 bagian 1, yaitu sebanyak 26 responden.

b. Apakah Anda sudah menerima vaksinasi COVID-19?

Tabel 5 Respons Penerimaan Vaksin COVID-19

\begin{tabular}{lll} 
Jawaban & Jumlah Responden & Persentase \\
\hline Sudah & 30 & $93,8 \%$ \\
\hline Belum, masih mempertimbangkan & 2 & $6,3 \%$ \\
\hline Belum, tidak akan & - & -
\end{tabular}

Berdasarkan data pada Tabel 5 tersebut dapat diketahui bahwa responden yang menjawab Sudah berjumlah $30(93,8 \%)$, responden yang menjawab Belum, masih mempertimbangkan berjumlah $2(18,8 \%)$, dan tidak ada responden yang menjawab Belum, tidak akan. Sehingga dapat disimpulkan bahwa mayoritas responden menjawab Sudah terkait pertanyaan 2 bagian 1 , yaitu sebanyak 30 responden.

c. Apabila ada vaksin COVID-19 baru, apakah Anda akan merimanya?

Tabel 6 Respons Penerimaan Vaksin COVID-19 Baru

\begin{tabular}{lll} 
Jawaban & Jumlah Responden & Persentase \\
\hline Ya & 19 & $59,4 \%$ \\
\hline Tidak yakin, masih mempertimbangkan & 11 & $34,4 \%$ \\
\hline
\end{tabular}


Hendry Naufal Marbella, Nadira Hanifah Nur'aini, Shafwan Agung, Nur Aini Rakhmawati

\begin{tabular}{lll}
\hline Tidak, tidak akan & 2 & $6,3 \%$
\end{tabular}

Berdasarkan data pada Tabel 6 tersebut dapat diketahui bahwa responden yang menjawab Ya berjumlah 19 (59,4\%), responden yang menjawab Tidak yakin, masih mempertimbangkan berjumlah $11(34,4 \%)$, dan responden yang menjawab Tidak, tidak akan berjumlah $2(6,3 \%)$. Sehingga dapat disimpulkan bahwa mayoritas responden menjawab Ya terkait pertanyaan 3 bagian 1, yaitu sebanyak 19 responden.

\section{Variabel Terkait Sumber Informasi dan Sosial Media}

a. Sumber informasi mana yang Anda percayai mengenai informasi COVID-19?

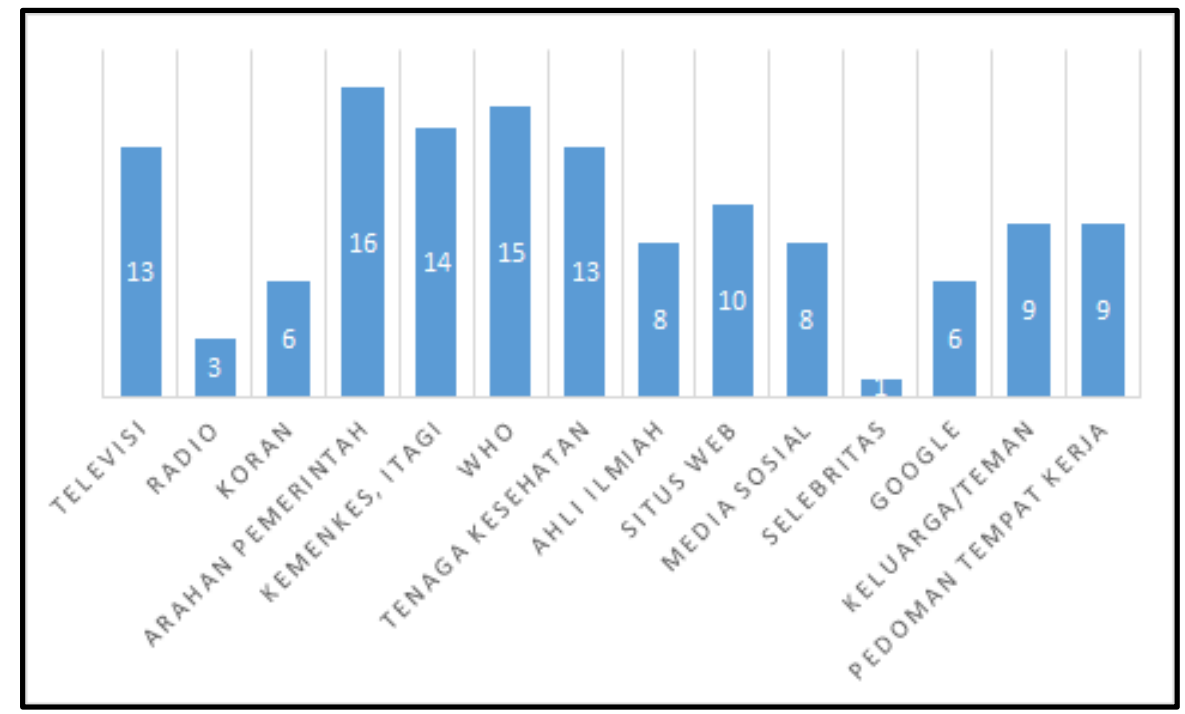

Gambar 1 Grafik Sumber Informasi yang Dipercaya

Berdasarkan data pada Gambar 1 dapat diketahui bahwa mayoritas responden menjawab Arahan pemerintah merupakan sumber informasi terpercaya mengenai COVID-19, yaitu sebanyak 16 responden. Diikuti dengan Otoritas kesehatan internasional (WHO) dan Otoritas kesehatan nasional (Kemenkes, ITAGI) sebanyak masing-masing 15 dan 14 responden.

b. Dalam satu bulan terakhir, rata-rata berapa lama waktu yang Anda habiskan tiap hari menggunakan media sosial?

Tabel 7 Respons Lama Penggunaan Media Sosial

\begin{tabular}{lll} 
Jawaban & Jumlah Responden & Persentase (\%) \\
\hline Tidak pernah & - & - \\
\hline Kurang dari 10 menit/hari & 2 & $6,3 \%$ \\
\hline 10-30 menit/hari & 1 & $3,1 \%$ \\
\hline $31-60$ menit/hari & 3 & $9,4 \%$ \\
\hline 1-2 jam/hari & 9 & $28,1 \%$ \\
\hline
\end{tabular}




\begin{tabular}{lll}
\hline 2-3 jam/hari & 4 & $12,5 \%$ \\
\hline Lebih dari 3 jam/hari & 13 & $40,6 \%$
\end{tabular}

Berdasarkan data pada Tabel 7 tersebut dapat diketahui bahwa responden tidak ada yang menjawab Tidak pernah, responden yang menjawab Kurang dari 10 menit/hari berjumlah $2(6,3 \%)$, yang menjawab 10-30 menit/hari berjumlah $1(3,1 \%)$, yang menjawab 31-60 menit/hari berjumlah 3 (9,4\%), yang menjawab 1-2 jam/hari berjumlah $9(28,1 \%)$, yang menjawab 2-3 jam/hari berjumlah 4 (12,5\%), dan yang menjawab lebih dari 3 jam/hari berjumlah 13 (40,6\%). Sehingga dapat disimpulkan bahwa mayoritas responden menjawab Lebih dari 3 jam/hari terkait pertanyaan 1 bagian 2, yaitu sebanyak 13 responden.

c. Platform media sosial apa yang Anda gunakan?

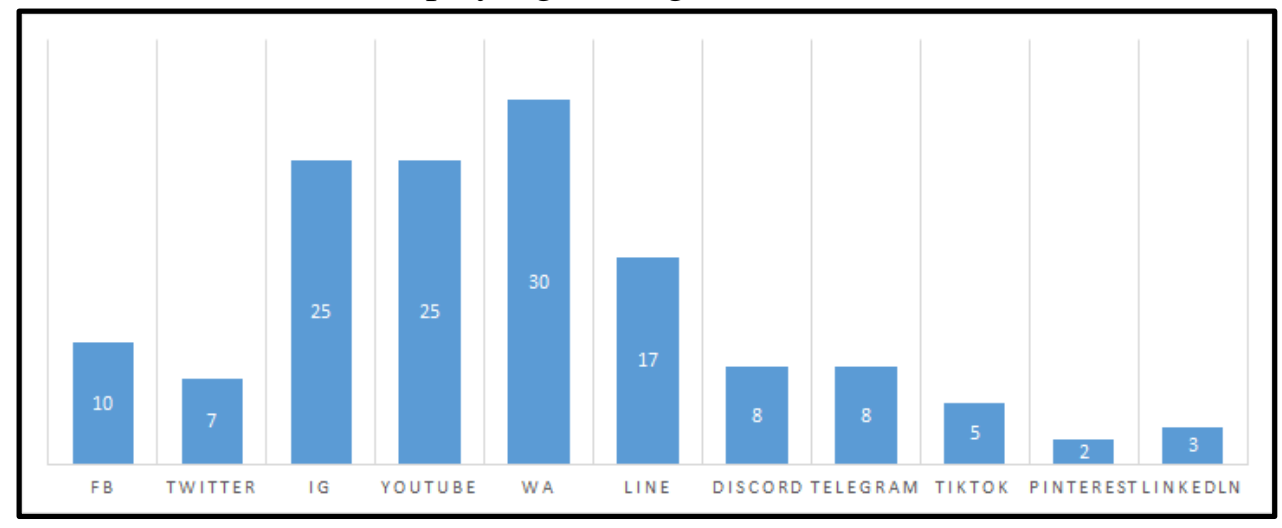

Gambar 2 Platform Media Sosial yang Digunakan

Berdasarkan data tersebut dapat diketahui bahwa mayoritas responden menggunakan platform media sosial WhatsApp, yaitu sebanyak 30 responden.

d. Di platform media sosial mana Anda menerima informasi mengenai COVID-19?

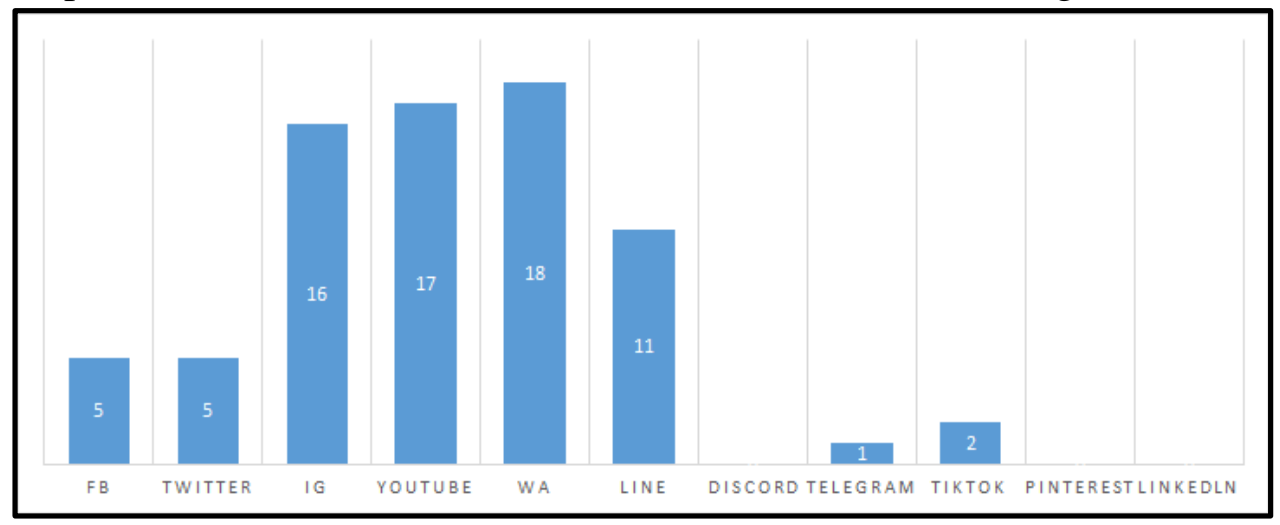

Gambar 3 Media Sosial yang Memberi Informasi 
Hendry Naufal Marbella, Nadira Hanifah Nur'aini, Shafwan Agung, Nur Aini Rakhmawati

Berdasarkan data pada Gambar 3 tersebut dapat diketahui bahwa mayoritas responden menerima informasi mengenai COVID-19 berasal dari platform media sosial Whatsapp, yaitu sebanyak 18 responden.

e. Dengan siapa Anda berbagi informasi mengenai COVID-19?

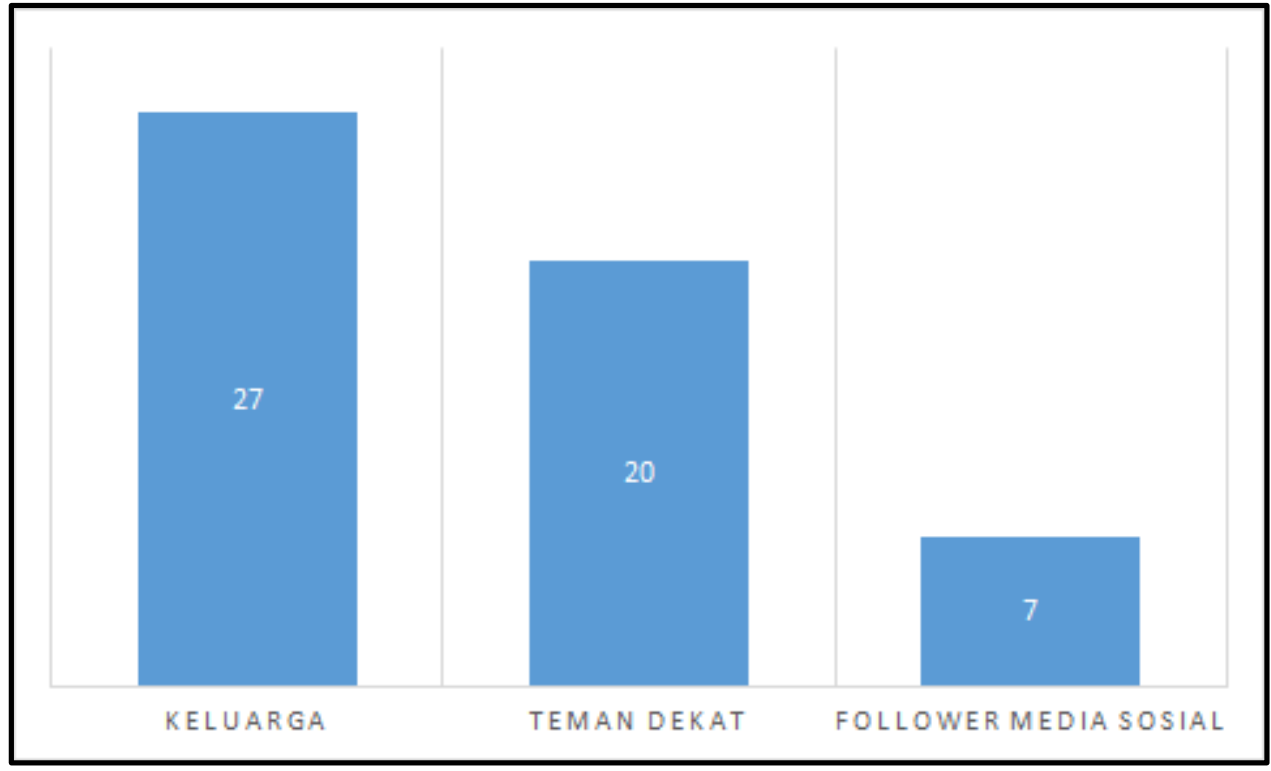

Gambar 4 Relasi Berbagi Informasi

Berdasarkan data pada Gambar 4 tersebut dapat diketahui bahwa mayoritas responden berbagi informasi mengenai COVID-19 dengan keluarga masing-masing, yaitu sebanyak 27 responden.

f. Di platform media sosial mana Anda berbagi informasi mengenai COVID-19?

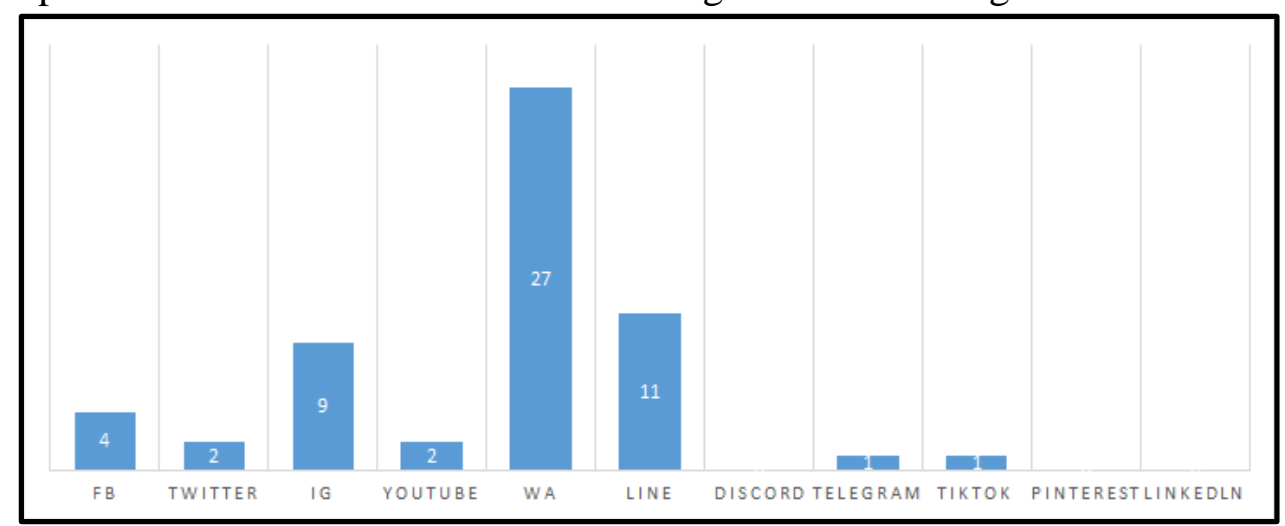

Gambar 5 Media Sosial Berbagi Informasi

Berdasarkan data pada Gambar 5 tersebut dapat diketahui bahwa mayoritas responden berbagi informasi mengenai COVID-19 melalui media sosial WhatsApp, yaitu sebanyak 27 responden.

\section{Variabel Terkait Eksposur Informasi Vaksinasi COVID-19}


Pada bagian ini penulis menunjukkan lima buah gambar yang menunjukkan berita bohong terkait vaksinasi. Di sini penulis menganalisis tanggapan para responden terkait gambar-gambar yang telah dicantumkan.

a. Setelah melihat gambar-gambar tersebut, apabila ada vaksin COVID-19 baru, apakah Anda akan merimanya?

Tabel 8 Respons Penerimaan COVID-19 Setelah Eksposur Berita Bohong Jawaban Jumlah Responden Persentase (\%)

\begin{tabular}{lll}
\hline Ya & 17 & $53,1 \%$ \\
\hline Tidak yakin, masih mempertimbangkan & 14 & $43,8 \%$ \\
\hline Tidak, tidak akan & 1 & $3,1 \%$
\end{tabular}

Berdasarkan data pada Tabel 8 tersebut dapat diketahui bahwa responden yang menjawab Ya berjumlah 17 (53,1\%), responden yang menjawab Tidak yakin, masih mempertimbangkan berjumlah 14 (43,8\%), dan responden yang menjawab Tidak, tidak akan berjumlah $1(3,1 \%)$. Sehingga dapat disimpulkan bahwa mayoritas responden menjawab Ya terkait pertanyaan 1 bagian 3, yaitu sebanyak 17 responden.

b. Secara umum, berdasarkan informasi pada gambar saya merasa ...

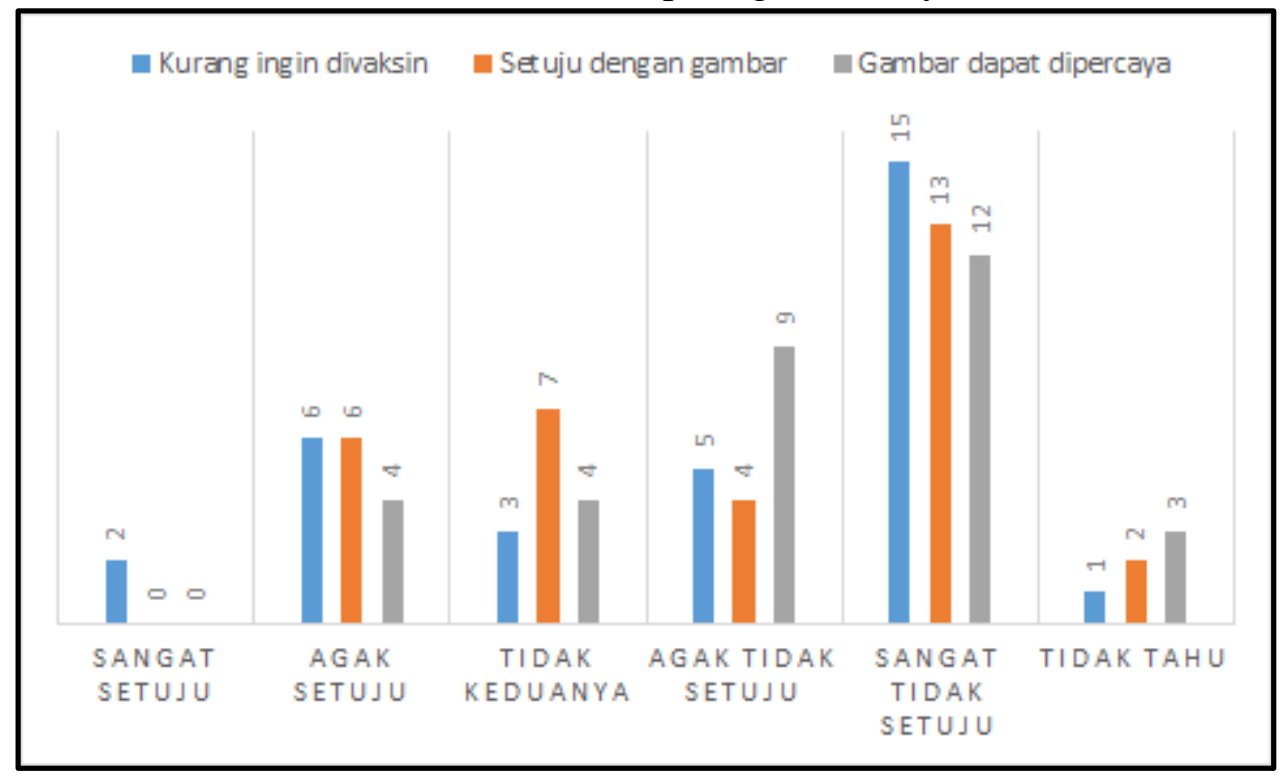

Gambar 6 Perasaan Responden Terhadap Gambar

Berdasarkan data pada Gambar 6 tersebut dapat diketahui bahwa secara keseluruhan mayoritas responden merasa sangat tidak setuju dengan informasi yang tercantum dalam gambar-gambar yang telah diberikan.

c. Secara umum, berdasarkan informasi pada gambar, saya akan ... 
Hendry Naufal Marbella, Nadira Hanifah Nur'aini, Shafwan Agung, Nur Aini Rakhmawati

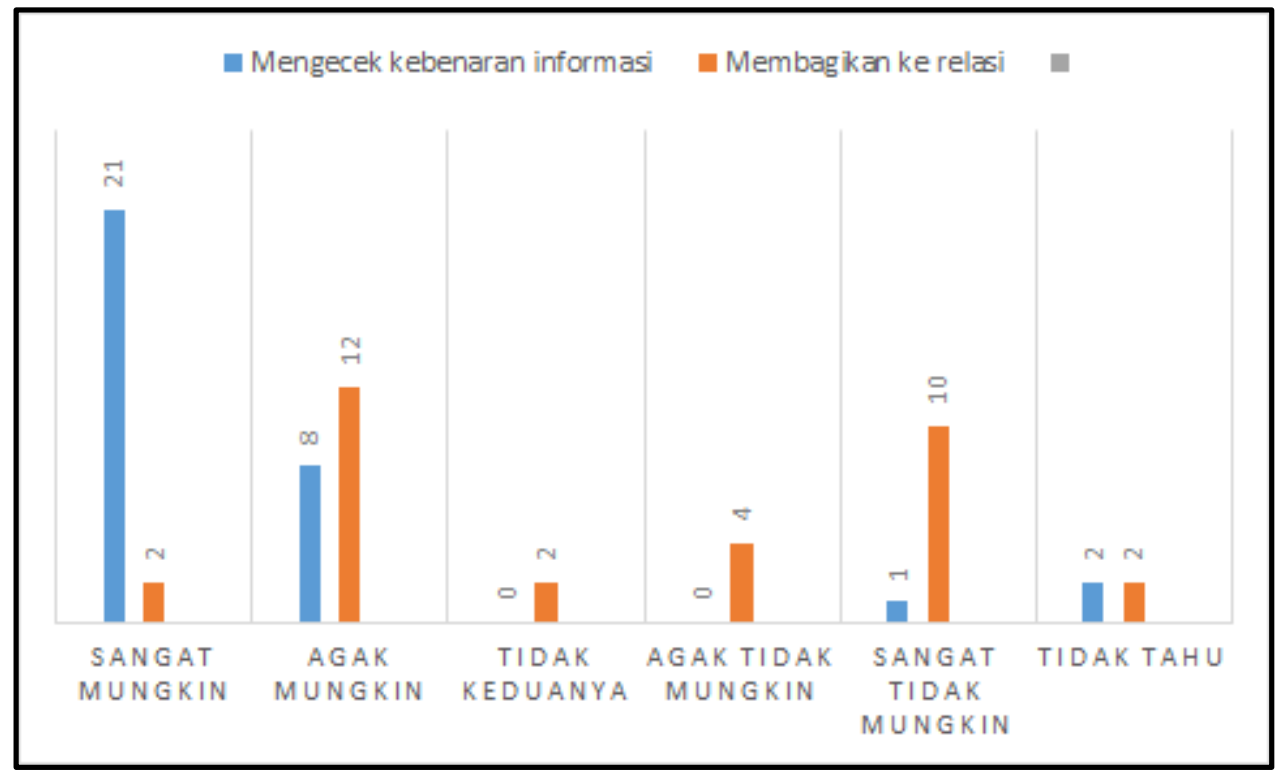

Gambar 7 Tindakan Responden Terkait Gambar

Berdasarkan data pada Gambar 7 tersebut dapat diketahui bahwa secara keseluruhan mayoritas responden sangat mungkin akan mengecek kebenaran atas informasi-informasi yang tercantum dalam gambar dan sangat tidak mungkin akan membagikan informasi-informasi dalam gambar tersebut kepada relasinya.

\section{Variabel Terkait Berbagi Informasi Vaksinasi COVID-19}

Pada bagian ini penulis menanyakan terkait media sosial yang digunakan oleh responden untuk membagikan informasi terkait vaksinasi COVID-19 pada satu bulan terakhir.

a. Pernahkah Anda melihat konten-konten yang mirip dengan gambar-gambar di atas di media sosial pada satu bulan terakhir?

Tabel 9 Respons Melihat Konten Berita Bohong di Media Sosial

\begin{tabular}{lll} 
Jawaban & Jumlah Responden & Persentase (\%) \\
\hline Ya & 13 & $40,6 \%$ \\
\hline Tidak & 15 & $46,9 \%$ \\
\hline Tidak tahu & 4 & $12,5 \%$ \\
\hline
\end{tabular}

Berdasarkan data pada Tabel 9 tersebut, didapatkan hasil bahwa responden yang menjawab Ya berjumlah 13 (40,6\%), menjawab Tidak berjumlah 15 (46,9\%), dan menjawab Tidak tahu berjumlah 4 (12,5\%). Sehingga dapat disimpulkan bahwa mayoritas responden menjawab Tidak pada pertanyaan 1 bagian 4, yaitu sebanyak 15 .

b. Seberapa sering Anda melihat konten yang mirip dibagikan di media sosial pada satu bulan terakhir? 
Tabel 10 Respons Frekuensi Melihat Konten Berita Bohong di Sosial Media

\begin{tabular}{lll} 
Jawaban & Jumlah Responden & Persentase (\%) \\
\hline Beberapa kali sehari & 1 & $3,1 \%$ \\
\hline Sekali atau dua kali sehari & 1 & $3,1 \%$ \\
\hline Beberapa kali seminggu & 3 & $9,4 \%$ \\
\hline Beberapa kali sebulan & 12 & $37,5 \%$ \\
\hline Tidak pernah & 7 & $21,9 \%$ \\
\hline Tidak tahu & 8 & $25 \%$ \\
\hline
\end{tabular}

Berdasarkan data pada Tabel 10 tersebut, didapatkan hasil bahwa responden yang menjawab Beberapa kali sehari berjumlah 1 (3,1\%), Sekali atau dua kali sehari berjumlah $1(3,1 \%)$, Beberapa kali seminggu berjumlah $3(9,4 \%)$, Beberapa kali sebulan berjumlah $12(37,5 \%)$, Tidak pernah berjumlah 7 (21,9\%), Tidak tahu berjumlah 8 (25\%). Sehingga dapat disimpulkan bahwa mayoritas responden menjawab Beberapa kali sebulan pada pertanyaan 2 bagian 4, yaitu sebanyak 12 .

c. Pernahkah Anda membagikan, menyukai, atau berkomentar pada konten yang mirip pada satu bulan terakhir?

Tabel 11 Respons Berinteraksi Dengan Konten Berita Bohong

\begin{tabular}{lll} 
Jawaban & Jumlah Responden & Persentase (\%) \\
\hline Ya & 1 & $3,1 \%$ \\
\hline Tidak & 31 & $96,9 \%$ \\
\hline Tidak tahu & - & - \\
\hline
\end{tabular}

Berdasarkan data pada Tabel 11 tersebut, didapatkan hasil bahwa responden yang menjawab Ya berjumlah 1 (3,1\%), Tidak berjumlah 31 (96,9\%), dan tidak ada yang menjawab Tidak tahu. Sehingga dapat disimpulkan bahwa mayoritas responden menjawab Tidak pada pertanyaan 3 bagian 4 , yaitu sebanyak 31 .

Secara garis besar dari beberapa analisis tersebut, ditemukan hasil yang cukup bertolak belakang dengan hasil penelitian terdahulu yang dilakukan di Amerika Serikat dan Britania Raya oleh (Loomba et al., 2021) Seperti yang terlihat di Tabel 6, semula terdapat 19 responden yang mau menerima vaksin COVID-19 baru, namun setelah diberi eksposur dengan berita bohong, dua responden berubah pikiran dan memilih untuk masih mempertimbangkannya seperti yang terlihat pada Tabel 8 . Hal ini bisa jadi karena para responden sudah jarang melihat adanya berita bohong di media sosial dan kebanyakan hanya pernah melihatnya sekali dalam satu bulan seperti yang terlihat pada Tabel 10 . Serta terlihat pula dari grafik di Gambar 7 kebanyakan responden merasa sangat memungkinkan untuk melakukan pengecekan fakta apabila melihat foto atau konten yang memiliki narasi mencurigakan seperti berita bohong yang telah penulis paparkan pada survei. 
Hendry Naufal Marbella, Nadira Hanifah Nur'aini, Shafwan Agung, Nur Aini Rakhmawati

\section{Kesimpulan}

Dari hasil penelitian pengaruh berita bohong di media sosial terhadap keputusan masyarakat Indonesia dalam melakukan vaksin COVID-19, dapat diambil kesimpulan bahwa masyarakat Indonesia yang berencana melakukan vaksinasi COVID-19 cenderung tetap kukuh pada pendiriannya untuk melakukan vaksinasi meskipun telah terpapar berita-berita yang menyesatkan. Hanya ada sebagian yang sangat kecil berubah pikirannya menjadi mempertimbangkan vaksinasi setelah melihat berita-berita tersebut. Hal ini dikarenakan masyarakat Indonesia kebanyakan hanya mempercayai informasi mengenai vaksin COVID-19 yang langsung bersumber dari pemerintah, otoritas kesehatan, maupun langsung dari seorang tenaga kesehatan. Meskipun mereka mendapatkan berita bohong melalui media sosial, kebanyakan cenderung melakukan pengecekan fakta terlebih dahulu sehingga menghentikan adanya persebaran berita bohong ke orang lain. Meskipun begitu, penelitian tambahan perlu terus dilakukan untuk mendapatkan hasil yang lebih konkret dan mencakup lebih banyak responden seluruh Indonesia. 


\section{Bibliografi}

Damaledo. (2021). 2 Maret 2020 kasus corona pertama di Indonesia diumumkan tahun lalu. Retrieved from tirto.id website: tirto.id: https://tirto.id/2-maret-2020-kasuscorona-pertama-di-indonesia-diumumkan-tahun-lalu-gaKw.

Dang, Hoang Linh. (2021). Social Media, Fake News, and the COVID-19 Pandemic: Sketching the Case of Southeast Asia. Austrian Journal of South-East Asian Studies, 14(1), 37-58. https://doi.org/10.14764/10.ASEAS-0054.

Dhewantara, P. W. (2021). Studi Terbaru: Vaksin COVID-19 Efektif Mencegah Perawatan dan Kematian. Retrieved from sehatnegeriku.kemkes.go.id website: https://sehatnegeriku.kemkes.go.id/baca/rilis-media/20210812/4238277.

Effendi, Sofian. (2012). Tukiran. Metode Penelitian Survei.

Ihsanuddin. (2020). Waspada Virus Corona, Pemerintah Siapkan 100 RS dengan Ruang Isolasi. Retrieved from https://nasional.kompas.com/read/2020/01/27/14590641/waspada-virus-coronapemerintah-siapkan-100-rs-dengan-ruang-isolasi website:

Kalia, B. S. (2021). Analisis Penyebaran Berita Hoaks Pandemi Covid-19 di Bondowoso Melalui Facebook.

Kemenkes. (2021). Program Vaksinasi COVID-19 Mulai Dilakukan, Presiden Orang Pertama Penerima Suntikan Vaksin COVID-19. Retrieved from http://p2p.kemkes.go.id/program-vaksinasi-covid-19-mulai-dilakukan-presidenorang-pertama-penerima-suntikan-vaksin-covid-19/ website:

Labs, Zignal. (2017). A report on the spread of fake news. Retrieved from http://go.zignallabs.com/Q1-2017-fake-news-report website:

Lazer, David M. J., Baum, Matthew A., Benkler, Yochai, Berinsky, Adam J., Greenhill, Kelly M., Menczer, Filippo, Metzger, Miriam J., Nyhan, Brendan, Pennycook, Gordon, \& Rothschild, David. (2018). The science of fake news. Science, 359(6380), 1094-1096. https://doi.org/10.1126/science.aao2998.

Loomba, Sahil, de Figueiredo, Alexandre, Piatek, Simon J., de Graaf, Kristen, \& Larson, Heidi J. (2021). Measuring the impact of COVID-19 vaccine misinformation on vaccination intent in the UK and USA. Nature Human Behaviour, 5(3), 337-348. https://doi.org/10.1038/s41562-021-01056-1.

Mafindo. (2021). Tentang kami. Retrieved from https://www.mafindo.or.id/tentangkami/ website: https://www.mafindo.or.id/tentang-kami/

Pranita, E. (2020). Virus corona di Indonesia bikin masyarakat panik, ini sebabnya. Retrieved from kompas.com website: https://www.kompas.com/sains/read/2020/03/12/071400823/virus-corona-di- 
Hendry Naufal Marbella, Nadira Hanifah Nur'aini, Shafwan Agung, Nur Aini Rakhmawati

indonesia-bikin-masyarakat-panik-ini-sebabnya?page=all

Rakhmawati, Nur Aini, Aditama, Muhammad Iqbal, Pratama, Rizqeya Irfan, \& Wiwaha, Kevin Hafizzana Untoro. (2020). Analisis Klasifikasi Sentimen Pengguna Media Sosial Twitter Terhadap Pengadaan Vaksin COVID-19. JIEET (Journal of Information Engineering and Educational Technology), 4(2), 90-92. https://doi.org/10.26740/jieet.v4n2.p90-92.

Saling, Lauren L., Mallal, Devi, Scholer, Falk, Skelton, Russell, \& Spina, Damiano. (2021). No one is immune to misinformation: An investigation of misinformation sharing by subscribers to a fact-checking newsletter. Plos One, 16(8), e0255702. https://doi.org/10.1371/journal.pone.0255702.

Schultz, A., \& Parikh, J. (2020). Keeping our services stable and reliable during the COVID-19 outbreak. Retrieved from https://about.fb.com/news/2020/03/keepingour-apps-stable-during-covid-19/ website: https://about.fb.com/news/2020/03/keeping-our-apps-stable-during-covid-19/.

Sugiyono. (2016). Metode Penelitian Kuantitatif, Kualitatif dan $R \& D$ (PT Alfabet). Bandung.

Wardle, C. (2020). Understanding information disorder. Diambil kembali dari First Draft. Retrieved from https://firstdraftnews.org/long-form-article/understandinginformation-disorder/ website: https://firstdraftnews.org/long-formarticle/understanding-information-disorder/

Zhu, Bi, Chen, Chuansheng, Loftus, Elizabeth F., He, Qinghua, Chen, Chunhui, Lei, Xuemei, Lin, Chongde, \& Dong, Qi. (2012). Brief exposure to misinformation can lead to long-term false memories. Applied Cognitive Psychology, 26(2), 301-307. https://doi.org/10.1002/acp.1825. 